\title{
Effect of Barley or Rape Seed Cake as Supplement to Silage for High-Yielding Organic Dairy Cows
}

\author{
Mogensen, L. and Kristensen, T. (Department of Agricultural Systems, \\ Danish Institute of Agricultural Sciences, Research Centre Foulum, \\ P.O. Box 50, DK-8830 Tjele, Denmark). Effect of barley or rape seed \\ cake as supplement to silage for high-yielding organic dairy cows. Re- \\ ceived January 30, 2002. Accepted September 25, 2002. Acta Agric. \\ Scand., Sect. A, Animal Sci. 52: 243-252, 2002. (C) 2002 Taylor \& \\ Francis.
}

An experiment was carried out to investigate the effects of barley or rape seed cake as supplement to silage given ad libitum on milk production and health of dairy cows. A total of 103 cows were divided into two groups on two farms. Before the experiment, the cows had an average milk yield of $26.9 \mathrm{~kg}$ ECM and they were in milk for an average of 99 days. Their average parity was 2.3 and their weight $596 \mathrm{~kg}$. The cows in each group received either solely barley or an isoenergetic mixture of rape cake seed and barley as supplement. The supplement feed was fed frequently by automatic feeding. A mixture of clover grass silage and whole crop silage was fed ad libitum.

The daily milk yields were not significantly different in the barley and rape seed cake treatment $(22.8 \mathrm{vs} 24.1 \mathrm{~kg})$. The milk fat content was not significant different either $(4.51 \%$ vs $4.35 \%)$. However, the protein content tended to be higher in the barley treatment $(3.51 \% \mathrm{vs}$ $3.45 \%$ ). But the energy corrected milk yield (ECM) was not significantly different in the barley and rape seed cake treatments either ( $24.2 \mathrm{vs} 24.9 \mathrm{~kg}$ ECM). No differences in health as indicated by clinical illness treated by the vet and somatic cell count (SCC) was seen.

It was concluded that barley and a mixture of isoenergic rape seed cake and barley had similar feeding value when used as supplement with a high proportion of easily digestible clover grass silage allocated ad libitum and frequently allocation of supplementary feed.

\section{Lisbeth Mogensen and Troels Kristensen}

Department of Agricultural Systems, Danish Institute of Agricultural Sciences, Research Centre Foulum, P.O. Box 50, DK-8830 Tjele, Denmark

Key words: dairy cow, health, milk yield, organic farming, silage, supplement.

\section{Introduction}

According to the new EU legislation, the ration for organic herds must be based entirely on organically grown feed as of 2005 as the latest (Council for the European Union, 1999). Furthermore, some of the major Danish dairies have claimed $100 \%$ organic feeding of the cows already from 2001. As the basic idea of organic farming is to supply the livestock on a farm with feed from locally grown crops, it will become natural that more and more feed in the ration is homegrown.

If the ration has to be based on home-grown products, which in Denmark typically includes clover grass pasture, clover grass silage, whole crop silage (either barley or a mixture of barley and pea), and 


\section{Mogensen and T. Kristensen}

barley, it will be difficult to meet the expected requirements for the nutrients to a high yielding dairy cow.

If the supplementary feed is changed from the typical, present organic feed including imported protein from conventional rape seed cake to consist only of barley, the level of protein, amino acids absorbed from the small intestine (AAT), and fatty acids in that ration will be lower than stipulated in the Danish recommendations (Strudsholm et al., 1999). This is assumed to lower the milk yield (Hermansen, 1993; Kristensen, 1997) and the level of starch may reach a critical level in relation to ruminal digestion (Agabriel et al., 1997) and health (Mortensen \& Hesselholt, 1986; Gasa et al., 1991). However, for dairy cows at pasture, Kristensen \& Aaes (1998) found that the type of supplementary feed was less critical than expected as the same milk yield was found for different combinations of supplementary feed (grain, rape seed cake). It was speculated that this was a result of a high proportion of clover grass in the diet. It can further be speculated that this might also be found for a winter ration with high quality clover grass silage. This was the background for the hypothesis that milk yield and health can be maintained at the same level for a ration with $100 \%$ organic barley as the only supplementary feed compared to a ration with barley and rape cake seed as supplementary feed, if the ration includes a high proportion of clover grass silage with high digestibility.

The aim of the present experiment was to examine the effect on milk production and health of either barley or an isoenergic mixture of rape seed cake and barley as supplement to silage ad libitum in the winter ration for dairy cows.

\section{Materials and methods}

The experiment was conducted during a four-month winter period from December 1997 to April 1998 on two organic dairy farms. On farm A, the Danish
Holstein cows were housed in tie-stalls with daily access to an exercise area with deep litter. The average yield per cow per year was $8900 \mathrm{~kg}$ milk $(4.19 \%$ fat and $3.47 \%$ protein). On farm B, the Red Danish cows were housed in a loose housing system with cubicles and concrete floor. The average yield per cow per year was $7000 \mathrm{~kg}$ milk $(4.18 \%$ fat and $3.60 \%$ protein).

\section{Treatments}

On each farm the cows were blocked two and two according to number of lactation, days from latest calving, and expected days to next calving and then randomly allocated to the two treatments. Cows on the rape seed cake treatment were fed $2.0 \mathrm{~kg}$ dry matter (DM) rape seed cake per cow per day on both farms. In addition, cows were fed $2.7 \mathrm{~kg}$ DM rolled barley on farm A and $3.1 \mathrm{~kg}$ DM barley on farm B. Cows in the barley treatment was fed barley as sole supplementary feed consistent with the same amount of energy in Scandinavian Feed Unit (SFU) as in the rape seed cake treatment. Therefore, cows in the barley treatment was fed $4.9 \mathrm{~kg}$ DM barley on farm $\mathrm{A}$ and $5.4 \mathrm{~kg}$ DM barley on farm B. The planned feeding of the two treatments on the two farms is shown in Table 1 and the nutrient content of the different feeds is shown in Table 2.

\section{Animals}

A total of 103 cows which were less than 27 weeks from latest calving were included in the experiment. On farm A, 37 cows with a daily milk yield of $29.0 \mathrm{~kg}$ and $603 \mathrm{~kg}$ live weight were included at the beginning of the experiment. 13 cows were included at calving during the experimental period. On farm B, 41 cows with a daily milk yield of $24.9 \mathrm{~kg}$ and $589 \mathrm{~kg}$ live weight were included at the beginning of the experiment. 12 cows were included at calving during the experimental period.

Table 1. Planned daily winter feeding $1997 / 98$ for the two treatments on the two farms, Dry Matter (DM) and Scandinavian Feed Unit (SFU) per cow per day

\begin{tabular}{|c|c|c|c|c|}
\hline \multirow{2}{*}{$\begin{array}{l}\text { Farm } \\
\text { Treatment } \\
\text { DM(SFU) }\end{array}$} & \multicolumn{2}{|l|}{ A } & \multicolumn{2}{|l|}{$\mathrm{B}$} \\
\hline & $\begin{array}{l}\text { Rape seed } \\
\text { cake }\end{array}$ & Barley & $\begin{array}{l}\text { Rape seed } \\
\text { cake }\end{array}$ & Barley \\
\hline Rape seed cake & $2.0(2.5)$ & 0 & $2.1(2.5)$ & 0 \\
\hline Barley & $2.7(3.0)$ & $4.9(5.5)$ & $3.1(3.5)$ & $5.4(6.0)$ \\
\hline Clover grass silage (ad lib) & \multicolumn{2}{|c|}{$10.1(9.0)$} & \multicolumn{2}{|c|}{$9.6(7.5)$} \\
\hline Whole crop silage (ad lib) & \multicolumn{2}{|c|}{$6.1(4.5)$} & \multicolumn{2}{|c|}{$5.7(4.5)$} \\
\hline Total kg DM (SFU) ${ }^{11}$ & $20.8(19.0)$ & $21.1(19.0)$ & $20.5(18.0)$ & $20.7(18.0)$ \\
\hline
\end{tabular}

${ }^{1)}$ Expected intake based on fill (Strudsholm et al., 1999). 
Table 2. Chemical composition and feeding value of the feed

\begin{tabular}{|c|c|c|c|c|c|c|c|c|}
\hline \multirow{2}{*}{$\begin{array}{l}\text { Farm } \\
\text { Feed }\end{array}$} & \multicolumn{4}{|l|}{$A$} & \multicolumn{4}{|l|}{ B } \\
\hline & $\begin{array}{l}\text { Rape } \\
\text { seed } \\
\text { cake }^{6)}\end{array}$ & Barley & $\begin{array}{l}\text { Clover } \\
\text { grass } \\
\text { silage }\end{array}$ & $\begin{array}{l}\text { Whole } \\
\text { crop - } \\
\text { barley }\end{array}$ & $\begin{array}{l}\text { Rape } \\
\text { seed } \\
\text { cake }^{7)}\end{array}$ & Barley & $\begin{array}{l}\text { Clover } \\
\text { grass } \\
\text { silage }\end{array}$ & $\begin{array}{l}\text { Whole } \\
\text { crop - } \\
\text { barley/pea }\end{array}$ \\
\hline \multicolumn{9}{|l|}{$\begin{array}{l}\text { Composition, g/kg DM: } \\
\text { Protein value }\end{array}$} \\
\hline Crude protein & 332 & 115 & 213 & 96 & 349 & 127 & 176 & 148 \\
\hline $\mathrm{AAT}^{4}$ & 119 & 103 & 59 & 66 & 153 & 104 & 62 & 66 \\
\hline $\mathrm{PBV}^{5}$ & 137 & -55 & 95 & -27 & 116 & -45 & 55 & 24 \\
\hline Fatty acids & 127 & 28 & 18 & 12 & 81 & 28 & 18 & 13 \\
\hline Crude fibre & 121 & 47 & 221 & 212 & 132 & 47 & 261 & 202 \\
\hline Starch & 24 & 581 & 15 & 226 & 46 & 581 & 16 & 241 \\
\hline Dig. cell walls & 211 & 125 & 479 & 339 & 243 & 125 & 438 & 312 \\
\hline \multicolumn{9}{|l|}{ Feeding value, per $\mathrm{kg}$ DM } \\
\hline $\mathrm{SFU}^{11}$ & 1.27 & 1.12 & 0.89 & 0.74 & 1.18 & 1.12 & 0.78 & 0.79 \\
\hline $\mathrm{DE}, \mathrm{MJ}^{2)}$ & 16.7 & 15.3 & 13.6 & 12.0 & 16.0 & 15.5 & 12.5 & 12.6 \\
\hline $\mathrm{ME}, \mathrm{MJ}^{3)}$ & 14.1 & 13.2 & 11.5 & 10.4 & 13.3 & 13.2 & 10.7 & 10.7 \\
\hline Digestibility in vitro, \% & - & - & 76 & 70 & - & - & 71 & 73 \\
\hline Protein degrad. EPN, \% & 59.3 & 65.2 & - & - & 52.7 & 65.9 & - & - \\
\hline \multicolumn{9}{|c|}{$\begin{array}{l}\text { 1) Scandinavian Feed Unit. } \\
\text { 2) Digested energy. } \\
\text { 3) Metabolizable energy. } \\
\text { 4) Amino acids absorbed in the small intestine. } \\
\text { 5) Protein balance in rumen. } \\
\text { 6) } 14 \% \text { crude fat. } \\
\text { 7) } 6 \% \text { crude fat. }\end{array}$} \\
\hline
\end{tabular}

\section{Feeding}

On farm A, the supplementary feed was fed individually from an automatic concentrate feeder five times a day. On farm B, the supplement feed was fed in an automatic feeding station at least four times a day. Clover grass silage and whole crop silage were fed $a d$ libitum in a mixture. The level of supplementary feed was increased to maximum level during the first two weeks of lactation on farm A and during the first week on farm B. All cows irrespectively of milk yield were fed the same amount of supplements during the experimental period.

\section{Recordings, analytical procedures, and calculations}

The intake of supplementary feed was recorded over 24 hours each day for the individual cow. The intake of ad libitum feed was recorded over 24 hours for all lactating cows in the herd every second week. The average feed intake of the ad libitum feed per cow per day was calculated as the total amount of ad libitum feed divided by number of lactating cows as the fill of the supplements was assumed to be identical.

Barley and rape seed cake was analyzed for protein degradation and digestibility using the nylon bag technique (Madsen et al., 1995) based on aggregated samples. Protein value in terms of AAT and PBV (protein balance in the rumen) was determined according to the Nordic Protein Evaluation System (Madsen et al., 1995). A total of 22 samples of grass silage and 12 samples of whole crop silage from farm A, and 12 samples of grass silage and 9 samples of whole crop silage from farm B were analyzed for dry matter, ashes, crude protein, crude fibres (Helrich, 1990), and in vitro digestibility of organic matter (Tilley \& Terry, 1963). Digestible cell walls and energy values were calculated according to Strudsholm et al. (1997). The content of starch in barley whole crop silage was estimated on the basis of content of crude protein and crude fibres according to Hermansen (1985).

Cows were weighed before the experiment, every month during the experiment, and at the end of the experiment. Individual milk yield and content of fat, protein and SCC were examined over one day every second week during the experiment. By means of the Danish Standard Method, the vet registered every veterinarian treatment. On farm $\mathrm{B}$, all cows were claw trimmed after the experimental period. For the description of the claw health the National Danish Claw Recording Scheme was used. 


\section{Mogensen and T. Kristensen}

Daily milk yield per cow was calculated as a simple average of all milk yield registrations during the experimental period. However, only milk yield recordings less than 36 weeks from latest calving were included. Each cows had an average of seven milk yield registrations included in that average. Energycorrected milk was calculated as defined by Sjaunja et al. (1990):

$$
\begin{aligned}
\mathrm{ECM}= & \text { Milk yield } *(383 * \text { fat } \%+ \\
& 242 \mathrm{p} * \text { protein } \%+780.8) / 3140
\end{aligned}
$$

Effect of treatment on milk yield ( $\mathrm{kg}$ ECM, kg milk, $\mathrm{kg}$ fat, $\mathrm{kg}$ protein) was analysed by the GLM procedure (SAS 1990) according to the following model:

Milk yield $=$ treatment + farm + treatment $*$ farm

+lactation number

+ treatment $*$ farm $*$ lactation number

+ days in milk (covariate)

+ days in milk $*$ lactation number (covariate)

+ yield before experiment (covariate),

where milk yield is the average milk yield per cow per day (kg ECM, kg milk, kg fat yield, kg protein yield); farm is the two different farms; treatment is the two different supplementary feed; lactation number is parity 1 or older; days in milk is the average interval from latest calving, and yield before experiment is the milk yield at the last milk yield recording before the experiment. For cows included at calving during the experiment was used a value of 0 and the data were standardized to an average of 0 and a standard deviation of 5 .

The consequence of production level in the pre-period or stage of lactation at the beginning of the experiment on the response of the treatment has been examined in an independent analysis. The cows were divided into three groups according to their production in the pre-period or days post partum at the beginning of the experiment.

Live weight gain was calculated as the difference between the weight at the end of the experiment and the weight immediately before the beginning of the experiment, and analyzed by the same model as for milk yield, but with weight before the experiment as covariate.

SCC was transformed by the logarithm and a simple average of all registrations per cow during the experimental period was calculated. The average value per cow was analyzed by the same model as milk yield, but with $\log (\mathrm{SCC})$ before the experiment as covariate.

Prevalence of diseases in the two treatments and on the two farms was analysed as $\chi^{2}$-tests.

\section{Results}

\section{Daily feed intake per cow}

Table 3 shows the daily feed intake per cow. As planned, the feed intake of the supplementary feed was at an equal energy (SFU) level in the two treatments. On farm A, the intake of the ad libitum feed was $16.2 \mathrm{~kg} \mathrm{DM}$ of which $64 \%$ originated from clover grass silage while the remaining $36 \%$ was whole crop barley silage. On farm B, the intake of the ad libitum feed was $14.4 \mathrm{~kg} \mathrm{DM}$ with the same proportion between clover grass silage and whole crop silage as on farm A. The proportion of roughage was $76 \%$ of DM on farm A and $73 \%$ on farm B. The two treatments had the same energy supply within farm. The levels of metabolizable and net energy were 245 $\mathrm{MJ} / 19.2 \mathrm{SFU}$ and $221 \mathrm{MJ} / 17.1 \mathrm{SFU}$ on farm A and $\mathrm{B}$, respectively. However, cows on farm B did not entirely achieve the planned ad libitum intake.

The barley ration had a lower level of AAT than the rape seed cake ration on both farms. However, because of a higher effective protein degradability (EPD) in rape seed cake $(59.3 \%$ on farm A and $52.7 \%$ on farm B) than expected from standard table value (50\% according to Strudsholm et al., 1997) the difference in AAT level between the two treatments was lower than expected. The level of AAT from rape seed cake was $119 \mathrm{~g} / \mathrm{kg}$ DM on farm A (154 g/kg DM expected) and $153 \mathrm{~g} / \mathrm{kg} \mathrm{DM}$ on farm B (165 g/ kg DM expected).

Also the level of fatty acids was lower in the barley ration than in the rape seed cake ration. The barley ration had $19 \mathrm{~g}$ fatty acids $/ \mathrm{kg}$ DM compared to 29 $\mathrm{g} / \mathrm{kg} \mathrm{DM}$ on the rape seed cake ration on farm A. On farm B, these levels were 19 and $24 \mathrm{~g} / \mathrm{kg} \mathrm{DM}$ on barley and rape seed cake rations, respectively. The level of starch was increased by $63 \mathrm{~g}$ per $\mathrm{kg} \mathrm{DM}$ on farm A and $55 \mathrm{~g}$ per $\mathrm{kg} \mathrm{DM}$ on farm B in the barley ration compared with the rape seed cake ration.

All rations had a high level of digestible cell walls. The levels of crude protein were 15.7 and $15.3 \%$ of $\mathrm{DM}$ in the barley rations versus 18.0 and $17.6 \%$ of $\mathrm{DM}$ in the rape seed cake rations. PBV were positive for all rations.

\section{Daily milk production}

Table 4 shows the average daily milk production and SCC in the two treatments on the two farms. There was no statistical significant difference in milk yield between the barley and rape seed cake treatments $(P=0.34)$. The mean values were 22.8 and 24.1 $\mathrm{kg}$ milk per cow day, respectively. The milk fat content was not significant different either $(P=$ $0.15)$. The mean values of milk fat content were $4.51 \%$ and $4.35 \%$, respectively. The protein content 
Effect of barley or rape seed cake

Table 3. Daily feed intake in Dry Matter (DM) per cow during the experiment for the two treatments on farms $A$ and $B$

\begin{tabular}{|c|c|c|c|c|}
\hline \multirow{2}{*}{$\begin{array}{l}\text { Farm } \\
\text { Treatment }\end{array}$} & \multicolumn{2}{|l|}{ A } & \multicolumn{2}{|l|}{ B } \\
\hline & Rape seed cake & Barley & Rape seed cake & Barley \\
\hline \multicolumn{5}{|c|}{ Restricted feed, kg DM per cow } \\
\hline Rape seed cake & 2.2 & 0 & 2.0 & 0 \\
\hline Barley & 2.6 & 5.0 & 3.3 & 5.3 \\
\hline \multicolumn{5}{|c|}{ Ad libitum feed, kg DM per cow } \\
\hline Clover grass silage & 10.3 & 10.3 & 9.1 & 9.1 \\
\hline Whole crop silage & 5.9 & 5.9 & 5.0 & 5.0 \\
\hline \multicolumn{5}{|l|}{ Total intake per cow } \\
\hline DM, kg & 20.9 & 21.2 & 19.7 & 19.7 \\
\hline SFU $^{1}$ & 19.2 & 19.2 & 17.1 & 17.1 \\
\hline $\mathrm{DE}, \mathrm{MJ}^{2}$ & 287 & 287 & 260 & 259 \\
\hline $\mathrm{ME}, \mathrm{MJ}^{3}$ & 245 & 246 & 221 & 221 \\
\hline \multicolumn{5}{|l|}{ per kg DM, g } \\
\hline Fatty acids & 29 & 19 & 24 & 19 \\
\hline Starch & 145 & 208 & 169 & 224 \\
\hline $\mathrm{AAT}^{4}$ & 73 & 71 & 79 & 74 \\
\hline PBV $^{5}$ & 47 & 25 & 35 & 18 \\
\hline Crude protein & 180 & 157 & 176 & 153 \\
\hline Dig. protein & 138 & 116 & 132 & 111 \\
\hline Dig. cell walls & 369 & 356 & 334 & 321 \\
\hline
\end{tabular}

1) Net energy, Scandinavian Feed Unit.

2) Digestible energy.

3) Metabolizable energy.

4) Amino acids absorbed in the small intestine.

${ }^{5)}$ Protein balance in rumen.

Table 4. Daily milk production and somatic cell counts (SCC) in the two treatments on the two farms during the experimental period, LSmeans and std err

\begin{tabular}{|c|c|c|c|c|c|c|c|c|c|}
\hline \multirow{4}{*}{$\begin{array}{l}\text { Farm } \\
\text { Treatment } \\
\text { Number of cows }\end{array}$} & \multicolumn{4}{|l|}{$A$} & \multicolumn{4}{|l|}{ B } & \multirow[b]{2}{*}{$\mathrm{P}_{\mathrm{T}}$} \\
\hline & \multicolumn{2}{|c|}{ Rape seed/barley } & \multicolumn{2}{|l|}{ Barley } & \multicolumn{2}{|c|}{ Rape seed/barley } & \multicolumn{2}{|l|}{ Barley } & \\
\hline & \multicolumn{2}{|c|}{26} & \multicolumn{2}{|c|}{24} & \multicolumn{2}{|c|}{25} & \multicolumn{2}{|c|}{28} & \\
\hline & 139 & 63 & 138 & 70 & 136 & 61 & 135 & 65 & \\
\hline $\mathrm{ECM}, \mathrm{kg}$ & 26.9 & 0.7 & 26.9 & 0.7 & 22.9 & 0.7 & 21.5 & 0.7 & 0.58 \\
\hline Milk, kg & 26.3 & 0.8 & 25.7 & 0.8 & 21.8 & 0.8 & 19.9 & 0.8 & 0.34 \\
\hline Fat, kg & 1.11 & 0.03 & 1.13 & 0.03 & 0.95 & 0.03 & 0.91 & 0.03 & 0.83 \\
\hline Fat, $\%$ & 4.28 & 0.09 & 4.40 & 0.09 & 4.41 & 0.09 & 4.61 & 0.08 & 0.15 \\
\hline Protein, kg & 0.87 & 0.02 & 0.87 & 0.02 & 0.76 & 0.02 & 0.71 & 0.02 & 0.53 \\
\hline Protein, \% & 3.36 & 0.05 & 3.43 & 0.05 & 3.53 & 0.04 & 3.60 & 0.04 & 0.08 \\
\hline $\log (\mathrm{SCC})$ & 5.09 & 0.14 & 5.21 & 0.14 & 5.08 & 0.14 & 5.07 & 0.13 & 0.57 \\
\hline $\mathrm{Kg} \mathrm{ECM/SFU}$ & 1.39 & & 1.39 & & 1.33 & & 1.25 & & \\
\hline
\end{tabular}

$\mathrm{P}_{\mathrm{T}}=$ effect of dietary treatment with farm $*$ treatment as error term.

tended to be higher in the barley treatment $(P=$ $0.08)$. The mean values of protein content were $3.51 \%$ and $3.45 \%$, respectively. However, the ECM yield was not significantly different $(P=0.58)$ with mean values of 24.2 and $24.9 \mathrm{~kg}$ per cow in the barley and rape seed cake treatments, respectively. The SCC was not different between the two treatments $(P=0.57)$. 


\section{Mogensen and T. Kristensen}

The differences in ECM yield, milk yield, milk fat and protein percentage between rape seed cake and barley treatment for cows grouped according to preexperimental yields or stage of lactation at the beginning of the experiment are shown for first and greater parity cows in Table 5 . The differences between treatments were higher for second or greater parity than for first parity cows. The yield of the cows fed rape seed cake exceeded the yield of the cows fed barley.
However, for second parity and older cows that calved during the experiment, the opposite was found. A great part of the difference of $3.2 \mathrm{~kg} \mathrm{ECM}$ in favour of the barley treatment can be explained by one cow in the rape seed cake treatment with an ECM yield of $17.0 \mathrm{~kg}$.

The nitrogen efficiency is presented in Table 6. The efficiency for converting dietary nitrogen to milk nitrogen is 23 and $26 \%$ of the cows fed the rape seed

Table 5. The characteristics of the pre-experimental grouping for low and high yields and in earliest, middle, and latest stage of lactation and differences in the experimental period between rape seed cake and barley treatment (a positive difference if rape seed cake $>$ barley treatment)

\begin{tabular}{|c|c|c|c|c|c|c|}
\hline \multirow{2}{*}{$\begin{array}{l}\text { Grouping } \\
\text { Group }\end{array}$} & \multicolumn{3}{|c|}{ Milk Yield } & \multicolumn{3}{|c|}{ Stage of lactation } \\
\hline & Calv. ${ }^{2)}$ & High & Low & Early ${ }^{21}$ & Middle & Late \\
\hline \multicolumn{7}{|l|}{ First parity } \\
\hline $\mathrm{N}$ & 9 & 16 & 16 & 9 & 16 & 16 \\
\hline Weeks post partum ${ }^{1)}$ & - & 12 & 15 & - & 9 & 19 \\
\hline Yield pre period, kg ECM & - & 25.4 & 20.7 & - & 23.3 & 22.8 \\
\hline Yield experiment, kg ECM & 24.6 & 22.9 & 19.6 & 24.6 & 21.6 & 20.9 \\
\hline \multicolumn{7}{|l|}{ Rape seed cake vs Barley, } \\
\hline kg ECM & 0.6 & 1.2 & 1.3 & 0.6 & 2.1 & 1.1 \\
\hline kg milk & 0.5 & 2.0 & 0.8 & 0.5 & 2.6 & 1.0 \\
\hline fat, \% & 0.12 & -0.34 & 0.14 & 0.12 & -0.27 & 0 \\
\hline protein, \% & -0.05 & -0.07 & 0.04 & -0.05 & -0.07 & 0.03 \\
\hline \multicolumn{7}{|l|}{ Second parity or greater } \\
\hline $\mathrm{N}$ & 16 & 22 & 24 & 16 & 23 & 23 \\
\hline Weeks post partum ${ }^{11}$ & - & 9 & 19 & - & 8 & 21 \\
\hline Yield pre period, kg ECM & - & 34.1 & 25.4 & - & 33.2 & 25.9 \\
\hline Yields experiment, kg ECM & 29.8 & 28.9 & 22.9 & 29.8 & 28.2 & 23.3 \\
\hline \multicolumn{7}{|l|}{ Rape seed cake vs Barley, } \\
\hline $\mathrm{kg} \mathrm{ECM}$ & -3.2 & 1.6 & 2.3 & -3.2 & 2.7 & 0.9 \\
\hline kg milk & -2.1 & 3.6 & 2.6 & -2.1 & 4.4 & 1.3 \\
\hline fat, \% & -0.23 & -0.49 & -0.15 & -0.23 & -0.50 & -0.10 \\
\hline protein, \% & -0.14 & -0.18 & -0.07 & -0.14 & -0.09 & -0.12 \\
\hline
\end{tabular}

1) At the beginning of the experiment.

2) Calved during the experimental period.

Table 6. Intake of nitrogen and excretion in milk and manure and utilization in the different treatments

\begin{tabular}{llllll}
\hline Farm & A & & & & \\
\cline { 2 - 3 } Treatment & Rape seed cake & Barley & & Rape seed cake & Barley \\
\hline Input from feed, g N/day & & & & \\
$\quad$ Supplementary feed & 165 & 92 & 179 & 108 \\
$\quad$ Roughage & 437 & 441 & 376 & 374 \\
$\quad$ Feed, total & 602 & 533 & 555 & 482 \\
Output, g N/day & & & & 112 \\
$\quad$ Milk & 137 & 137 & 121 & 370 \\
$\quad$ Faces and urine & 465 & 396 & 434 & 23 \\
Utilisation, \% & 23 & 26 & 22 & \\
\hline
\end{tabular}


cake and barley ration on farm A, but 22 and $23 \%$ of the cows fed the rape seed cake and barley ration on farm $B$.

\section{Live weight gain during the experiment}

Live weight gain during the experiment and the average weight at the beginning of the experiment are given in Table 7. Overall, cows lost weight during the experiment. However, this weight loss was not affected by the type of supplementary feed $(P=0.72)$. Only cows close to calving lost weight, whereas cows far from calving gained weight.

\section{Health during the winter period}

The prevalence of difference disorders is shown in Table 8 . No difference in the frequency of disorders between the two treatments was found on either farm $(P=0.99)$.
As presented in Table 9, there was no difference in claw health between the two treatments on farm B. A mild heel erosion was seen for 44 out of 48 claw trimmed cows. A humid concrete floor with use of scraper in the loose housing could probably explain this.

\section{Discussion}

The present experiment has supported the hypothesis that it is possible to feed a high yielding cow barley as the only supplementary feed in the winter period and maintain the same level of milk yield as for a mixed supplement with rape seed cake and barley.

Traditionally is expected a negative effect on milk yield of a barley ration due to a lower content of AAT and fatty acids and a higher level of starch than in a ration with both rape seed cake and barley. The lack of treatment effects in the present experiment

Table 7. Live weight gain during the experiment and the average weight at the beginning of the experiment in the two treatments on the two farms, Lsmeans and std err

\begin{tabular}{|c|c|c|c|c|c|c|c|c|c|}
\hline \multirow{2}{*}{$\begin{array}{l}\text { Farm } \\
\text { Treatment }\end{array}$} & \multicolumn{4}{|l|}{$A$} & \multicolumn{4}{|l|}{ B } & \multirow[b]{2}{*}{$P_{\mathrm{T}}$} \\
\hline & \multicolumn{2}{|c|}{$\begin{array}{l}\text { Rape seed/ } \\
\text { barley }\end{array}$} & \multicolumn{2}{|c|}{ Barley } & \multicolumn{2}{|c|}{$\begin{array}{l}\text { Rape seed/ } \\
\text { barley }\end{array}$} & \multicolumn{2}{|c|}{ Barley } & \\
\hline $\mathrm{N}$ & \multicolumn{2}{|c|}{22} & \multicolumn{2}{|c|}{22} & \multicolumn{2}{|c|}{20} & \multicolumn{2}{|c|}{21} & \\
\hline Gain, kg & 0 & 8 & -7 & 7 & -5 & 9 & -4 & 8 & 0.63 \\
\hline Weight at the beginning, $\mathrm{kg}$ & 609 & 8 & 625 & 7 & 573 & 9 & 594 & 8 & \\
\hline
\end{tabular}

$\mathrm{P}_{\mathrm{T}}=$ effect of dietary treatment with farm $*$ treatment as error term.

Table 8. Frequency of different types of disorders on the two farms and in the two treatments

\begin{tabular}{|c|c|c|c|c|c|}
\hline \multirow{2}{*}{$\begin{array}{l}\text { Farm } \\
\text { Treatment }\end{array}$} & & \multicolumn{2}{|l|}{ A } & \multicolumn{2}{|l|}{ B } \\
\hline & & Rape seed/barley & Barley & Rape seed/barley & Barley \\
\hline \multicolumn{2}{|c|}{ Total number of cows at risk } & 23 & 22 & 25 & 28 \\
\hline \multirow[t]{2}{*}{ Mastitis } & total number of cows & 4 & 2 & 8 & 6 \\
\hline & frequency & 0.17 & 0.09 & 0.32 & 0.21 \\
\hline \multirow[t]{2}{*}{ Reproductive $^{11}$} & total number of cows & 2 & 0 & 4 & 1 \\
\hline & frequency & 0.09 & 0 & 0.16 & 0.04 \\
\hline \multirow[t]{2}{*}{ Digestion/metabolic ${ }^{2)}$} & total number of cows & 4 & 2 & 1 & 2 \\
\hline & frequency & 0.17 & 0.09 & 0.04 & 0.07 \\
\hline \multirow[t]{2}{*}{$\operatorname{Lim}^{3 \prime}$} & total number of cows & 1 & 0 & 5 & 2 \\
\hline & frequency & 0.04 & 0 & 0.20 & 0.07 \\
\hline \multirow[t]{2}{*}{ Problems at calving ${ }^{4}$} & total number of cows & 2 & 2 & 4 & 3 \\
\hline & frequency & 0.09 & 0.09 & 0.16 & 0.11 \\
\hline \multirow[t]{2}{*}{ Disorders in total } & total number of cows ${ }^{5)}$ & 10 & 8 & 15 & 10 \\
\hline & frequency & 0.43 & 0.36 & 0.60 & 0.36 \\
\hline
\end{tabular}

\footnotetext{
1) Uterus inflammation, retained placenta, vaginitis.

2) Foreign bodies, digestive disorders, paralysis due to calcium deficit at calving, acidosis, bloat.

3) Foot rot, arthritis, sole ulcer, pressure bruise.

4) Abortion, stillborn calf, calf dead during the first 24 hours, and difficult calving with assistance.

${ }^{5)}$ Each cow is counted only once.
} 


\section{Mogensen and T. Kristensen}

Table 9. Results from claw trimming on farm B after the winter experiment

\begin{tabular}{lrlrl}
\hline $\begin{array}{l}\text { Treatment } \\
\text { Cows claw trimmed, total N }\end{array}$ & \multicolumn{2}{l}{ Rape seed cake } \\
$23^{1)}$ & \multicolumn{2}{l}{$\begin{array}{l}\text { Barley } \\
25^{1)}\end{array}$} \\
\hline Hollow wall in hoof capsule & 1 & $(1$ hoof) & 1 & (1 hoof) \\
Sole ulcer & 1 & $(1$ hoof $)$ & 0 & (1 hoof) \\
Underrun sole & 1 & $(1$ hoof $)$ & 1 & (2 hooves or more) \\
Sole haemorrhage & 12 & $(2$ hooves or more) & 13 & (2 hooves or more) \\
Red/white line & 4 & $(2$ hooves or more) & 4 & \\
Heel erosion/slurry heel & 21 & & 23 & \\
\hline
\end{tabular}

1) Two cows in treatment rape seed cake and three cows in treatment barley were not claw trimmed.

could be due to the fact that the difference in AAT level between the two treatments was lower than expected. However, a positive interaction with a high share of roughage of high quality and the fact that the negative effect of starch may have been cancelled by frequently allocation may be the main explanation.

The expected milk yield reduction caused by a lower AAT level was $0.3 \mathrm{~kg}$ milk per gram AAT is reduced below $90 \mathrm{~g} / \mathrm{SFU}$ (Kristensen, 1997). In the present experiment, the differences in AAT between treatments were smaller than expected due to a high EPD in the rape seed cake. The rape seed cake ration contained $80 \mathrm{~g}$ AAT/SFU versus $78 \mathrm{~g}$ in the barley ration on farm $\mathrm{A}$, and $91 \mathrm{~g}$ versus $85 \mathrm{~g} \mathrm{AAT} / \mathrm{SFU}$ on farm B. However, the AAT difference between treatments was larger according to the French PDI system (Verite et al., 1979). This is because the Nordic AAT-PBV system relates the microbial protein synthesis to the amount of digested carbohydrates, whereas the French system relates to digested organic matter, which results in a higher estimation of the protein value of concentrates rich in fat and protein. However, in both systems only the barley treatment on farm $\mathrm{A}$ is in shortage of AAT according to the requirement based on maintenance and milk production (Madsen, 1985). On the other hand, only cows in the rape seed cake treatment on farm $B$ fulfil the recommendations based on energy allocation $(90 \mathrm{~g}$ AAT/SFU) used at present in Denmark (Madsen et al., 1995; Strudsholm et al., 1999).

The rations in the present study include a high proportion of ad libitum feed based mainly on easily digested clover grass silage resulting in an optimal rumen environment supplied with plenty of fermentable carbohydrate. This may have stimulated the microbial protein synthesis in the rumen, and the utilization of the digestible protein in rumen may have increased and the ration reached a higher level of AAT than calculated by the Nordic Protein Evaluation System. In general, the microbial protein synthesis is higher in rations high in roughage compared with ones high in concentrate (Hvelplund \& Madsen,
1985). In addition to that, the microbial protein synthesis is higher for fresh grass than for other feedstuffs (Madsen, 1985). This could also be the case for high quality clover grass silage (Kristensen \& Aaes, 1998). Experiments with supplementary feeding of dairy cows at pasture support our hypothesis as Kristensen \& Aaes (1998) found that when considerable amounts of grass were included in the ration there were no production effect of differences in AAT up to $25 \mathrm{~g} / \mathrm{SFU}$.

The efficiency of converting dietary nitrogen $(\mathrm{N})$ into milk nitrogen is, in the present experiment, at a low level of $22-23 \%$ compared to the average of $26 \%$ found for cows during winter feeding (Nielsen \& Kristensen, 2001). According to Van Vuuren \& Meijs (1987) the theoretical level of $\mathrm{N}$ efficiency may be as high as $40 \%$ for rations optimized at amino acid level. The general low level of $\mathrm{N}$ efficiency in the present experiment may be assigned to the high share of clover grass silage in the rations (Tamminga, 1996). However, the type of supplementation was also found to affect nitrogen utilization in dairy cows fed grass silage diets (Castillo et al., 2001) and cows fed the barley ration on farm $\mathrm{A}$ in the present experiment had a higher utilization of nitrogen $(26 \%)$ than those in the other treatments. This may be explained by the low level of crude protein in the ration, but high efficiency for converting feed to milk. However, the rape seed cake ration was expected to have a higher $\mathrm{N}$ efficiency than the barley ration, as rape seed cake is found to have a much higher score for content of the first limiting amino acids - histidine, methionine, and lysine - than barley (Schingoethe \& Blair, 1996; Vanhatalo et al., 1999).

The energy efficiency for milk production was higher on farm A (1.4 kg ECM/SFU) than on farm B (1.3 kg ECM/SFU). This may be due to the fact that the digestibility of the clover grass silage, which makes up half the ration, was higher on farm A than on farm B. The energy efficiency of the rape seed cake ration was higher than that of the barley ration on farm B. This indicates that the composition of the more disharmonious barley ration becomes more im- 
portant under the poorer roughage conditions on farm B.

Traditionally, a high level of starch in the ration is assumed to cause digestive interactions (Agabriel et al., 1997). However, Stensig et al. (1998) showed that it was possible to increase the level of starch from 20 to $30 \%$ of DM without the digestion of NDF in grass silage being decreased. In the present experiment, the barley ration included $22 \%$ of DM from starch and the allocation over 24 hours was divided into several rations. Further, the utilization of AAT for milk production is also dependent on the intestinal starch supply (Hurtaud et al., 1998; Knowlton et al., 1998; Hurtaud et al., 2000; Arieli et al., 2001), and starch digested postruminally is probably more efficiently used for milk synthesis than that digested in the rumen (Nocek \& Tamminga, 1991; Knowlton et al., 1998). As the barley treatment will probably have a higher bypass supply, this can also be one of the explanations why milk production was maintained at the same level as the one for rape seed cake treatment.

In general, a good state of health was found on both farms and there were no differences between the two treatments. Therefore, there is no reason to believe that the applied rations should have any negative effect on the cows' health. Although highdegradable starch such as barley can induce rumen acidosis and carried effect on hoof status, evidence from earlier work (Gasa et al., 1991) suggests that this is unlikely to be a problem in diets containing high proportions of grass silage and where starch has been divided into several rations as in the present experiment. However, on farm A the cows on the barley supplementation had a higher level of somatic cell count than cows on the mixed supplementation. Barnouin et al. (1995) confirmed these findings from herd studies as high quantities of cereal based supplement in the diet increased the risk for high somatic cell counts.

The present experiment suggests that it is possible for a Danish organic dairy farm to be self-supplied with homegrown feed even at a high level of milk production. For a ration high in easily digestible clover grass silage allocated ad libitum it was possible to feed the cows $100 \%$ homegrown organic feed (barley, clover grass silage, and barley whole crop silage) without any negative effect on milk yield. A positive effect of a high proportion of clover grass silage on rumen metabolism is probably the main explanation. Self-supply with organic feed can, therefore, be based on a simple crop rotation with clover grass for pasture and silage and barley for whole crop silage and supplement.

\section{Acknowledgements}

The authors express their thanks to the farmers, Kurt Juel and Vagn Spangsege, for letting their herds be available for the experiment, the research assistants, Niels Thomsen and Gunnar Grønning, for doing the entire on-farm registration, and senior researcher, Martin Weisbjerg and assistant, Ejner Serup for making the protein degradation analyses using nylon bags.

\section{References}

Agabriel, C., Coulon, J. B., Journal, C. \& Bony, J. 1997. Effect of concentrate type and distribution method on milk fat content and milk production in dairy cows. Ann. Zootech. 46, 417-425.

Arieli, A., Abramson, S., Mabjeesh, S. J., Zamwel, S. \& Bruckental, I. 2001. Effect of site and source of energy supplementation on milk yield in dairy cows. J. Dairy Sci. 84, 462-470.

Barnouin, J., Chassagne, M. \& Aimo, I. 1995. Dietary factors associated with milk somatic cell counts in dairy cows in Brittany, France. Preventive Veterinary Medicine. 21, 299-311.

Castillo, A. R., Kebreab, E., Beever, D. E., Barbi, J. H., Sutton, J. D., Kirby, H. C. \& France, J. 2001. The effect of energy supplementation on nitrogen utilization in lactating dairy cows fed grass silage diets. J. Anim. Sci. 79, 240-246.

Council for the European Union. 1999. Ordinance No 1804/1999 of July 1999. Supplementing Regulation (EEC) No 2092/91. Official Journal of the European Union L 222. Bruxelles, 28 pp.

Gasa, J., Holtenius, K., Sutton, J. D., Dhanoa, M. S. \& Napper, D. J. 1991. Rumen fill and digesta kinetics in lactating Friesian cows given two amounts of concentrates with two types of grass silage ad libitum. Br. J. Nutr. 66, 381-398.

Helrich, K. 1990. Official methods of the analysis of the AOAC. 15th edition. Association of the Official Analytical Chemists. 684 pp.

Hermansen, J. E. 1993. Influence of different types and levels of dietary fat for dairy cows at production within the milk quota system. Report 628. DIAS, Denmark. 69-87. (In Danish.)

Hermansen, J. E. 1985. Content of starch in whole crop silage of spring barley and maize grown in Denmark. Report 596. DIAS, Denmark. 54-59. (In Danish.)

Hurtaud, C., Lemosquet, S. \& Rulquin, H. 2000. Effect of graded duodenal infusions of glucose on yield and composition of milk from dairy cows. 2. Diets based on grass silage. J. Dairy Sci. 83, 2952-2962.

Hurtaud, C., Rulquin, H. \& Verite, R. 1998. Effects of graded duodenal infusions of glucose on yield and composition of milk from dairy cows. 1. Diets based on corn silage. J. Dairy Sci. 81, 3239-3247.

Hvelplund, T. \& Madsen, J. 1985. Amino acids passage to the small intestine in dairy cows compared with estimates of microbial protein and undegraded dietary protein from analyses in feed. Acta Agri. Scand. Suppl. 25, 21-36.

Knowlton, K. F., Dawson, T. E., Glenn, B. P., Huntington, G. B. \& Erdman, R. A. 1998. Glucose metabolism and milk yield of cows infused abomasally or ruminally with starch. J. Dairy Sci. $81,3248-3258$.

Kristensen, T. \& Aaes, O. 1998. Supplementary feeding of dairy cows at continuous grazing-influence of the protein value of the supplement on production, reproduction and health. Report 3. DIAS, Denmark. 39 pp. (In Danish.)

Kristensen, V. F. 1997. Optimal proteinforsyning (Optimal protein supply). Internal report No. 88. DIAS, Denmark. 46-55. (In Danish.) 


\section{Mogensen and T. Kristensen}

Madsen, J. 1985. The basis for the proposed Nordic protein evaluation system for ruminants. The AAT-PBV system. Acta Agri. Scand. 25, 9-20.

Madsen, J., Hvelplund, T., Weisbjerg, M. R., Bertilsson, J., Olsson, I., Spörndly, R., Harstad, O. M., Volden, H., Tuori, M., Varvikko, T., Huhtanen, P. \& Olafsson, B.L. 1995. The AAT/PBV protein evaluation system for ruminants. A revision. The Norwegian Journal of Agricultural Sciences 19, 1-37.

Mortensen, K. \& Hesselholt, M. 1986. The effect of high concentrate diet on the digital health of dairy cows. Proceedings of the $6^{\text {th }}$ international conference on production disease in farm animals, Belfast. 67-71.

Nielsen, N. M. \& Kristensen, T. 2001. Nitrogen excretion and efficiency from dairy cows at herd level on practical dairy farms in Denmark. DJF Report No. 33, 1-34. (In Danish.)

Nocek, J. E. \& Tamminga, S. 1991. Site of digestion of starch in the gastrointestinal tract of dairy cows and its effect on milk yield and composition. J. Dairy Sci. 74 (10), 3598-3629.

SAS Institute Inc. 1990. SAS/STAT User's Guide, Vol. 2. Vers. $6,4^{\text {th }}$ edition. Gary, NC. $893-1686$.

Schingoethe, D. J. \& Blair, R. 1996. Balancing the amino acid needs of the dairy cow. Animal Feed Science and Technology. $60,153-160$.

Sjaunja, L. O., Baevre, L., Junkkarinen, L., Pedersen, J. \& Setälä, J.A. 1990. Nordic proposal for an energy-corrected milk (ECM) formula. ICRPMA. 27 th session, Paris 2-6 July.

Stensig, T., Weisbjerg, M. R. \& Hvelplund, T. 1998. Digestion and passage kinetics of fibre in dairy cows as affected by the proportion of wheat starch or sucrose in the diet. Acta Agri. Scand. 48, 129-140.
Strudsholm, F., Nielsen, E. S., Flye, J. C., Kjeldsen, A. M., Weisbjerg, M. R., Søegaard, K., Kristensen, V. F., Hvelplund, T. \& Hermansen, J. E. 1997. Fodermiddeltabel 1997 (Feed tables. Composition and nutritional value for cattle). Report No. 69. The National Committee on Cattle Husbandry. Denmark. 53 pp. (In Danish.)

Strudsholm, F., Aaes, O., Madsen, J., Kristensen, V. F., Andersen, H. R., Hvelplund, T. \& Østergaard, S. 1999. Danske fodernormer til kvæg (Danish feed recommandations for cattle). Report No. 84. The National Committee on Cattle Husbandry. Denmark. 47 pp. (In Danish.)

Tamminga, S. 1996. A review on environmental impacts of nutritional strategics in ruminants. J. Anim. Sci. 74, 3112-3214.

Tilley, J. M. A. \& Terry, R. A. 1963. A two-stage technique for the in vitro digestion of forage crops. J. British Grassl. Soc. $18,104-111$.

Vanhatalo, A., Huhtanen, P., Toivonen, V. \& Varvikko, T. 1999. Response of dairy cows fed grass silage diets to absomasal infusions of histidine alone or in combinations' with methionine and lysine. J. Dairy Sci. 82, 2674-2685.

Van Vuuren \& Meijs, J. A. 1987. Effects of herbage composition and supplement feeding on the excretion of nitrogen in dung and urine by grazing dairy cows. In: Van der Meer, H., Unwin, R., Van Dijk, G. \& Ennik, G. (eds.). Animal manure on grassland and fodder crops. Wageningen, Netherlands. 1725.

Verite, R., Journet, M. \& Jarrige, R. 1979. A new system for the protein feeding of ruminants: the PDI system. Livest. Prod. Sci. 6, 349-367. 